\title{
A Phase II Study of Antineoplastons A10 and AS2-1 in Patients with Brainstem Gliomas. The Report on Non-Diffuse Intrinsic Pontine Glioma (Protocol BT-11)
}

\author{
Stanislaw R. Burzynski, Tomasz J. Janicki, Gregory S. Burzynski, Ania Marszalek \\ Burzynski Clinic, Houston, TX, USA \\ Email: srb@burzynskiclinic.com
}

Received 12 March 2015; accepted 10 April 2015; published 13 April 2015

Copyright @ 2015 by authors and Scientific Research Publishing Inc.

This work is licensed under the Creative Commons Attribution International License (CC BY). http://creativecommons.org/licenses/by/4.0/

(c) (i) Open Access

\begin{abstract}
Inoperable brainstem gliomas (BSG) are among the most difficult to treat malignancies. In the intent-to-treat (ITT) population of the BT-11 study for BSG, forty patients (median age 11.2 years old) were enrolled. Antineoplastons A10 and AS2-1 (ANP) were administered intravenously daily. The median daily dose of A10 was $8.70 \mathrm{~g} / \mathrm{kg} /$ day and AS2-1 was $0.32 \mathrm{~g} / \mathrm{kg} / \mathrm{day}$. Efficacy analyses were conducted in two subgroups: recurrent pediatric diffuse intrinsic pontine glioma (RPDIPG, $N=17$ ) and non-diffuse intrinsic pontine glioma (NDIPG, $N=11$ ). This paper reports the results of the study of the efficacy and safety of ANP in patients with NDIPG. The results in the RPDIPG group were reported before; complete response (CR) was $6 \%$, partial response (PR) $23.5 \%$, and stable disease (SD) $17.6 \%$. One year overall survival $(O S)$ was $29.4 \%, 2$ years $11.8 \%$, and 5,10 , and 15 years $6 \%$. In the NDIPG group, there were $36 \%$ CR and $27.5 \%$ SD. OS at $1,5,10$, and 15 years was $82 \%, 73 \%, 62 \%$, and $50 \%$ correspondingly. There was only one serious adverse event $(9 \%)$ reported in NDIPG represented by hypokalemia, Grade 4 . The results suggest that ANP shows efficacy and an acceptable tolerability profile in patients with RPDIPG and NDIPG.
\end{abstract}

\section{Keywords}

Antineoplastons A10 and AS2-1, Brainstem Glioma, Diffuse Intrinsic Pontine Glioma, Phase 2 Clinical Trial, Recurrent Glioma

\section{Introduction}

The brainstem connects the cerebrum and spinal cord and occupies one of the most important strategic locations

How to cite this paper: Burzynski, S.R., Janicki, T.J., Burzynski, G.S. and Marszalek, A. (2015) A Phase II Study of Antineoplastons A10 and AS2-1 in Patients with Brainstem Gliomas. The Report on Non-Diffuse Intrinsic Pontine Glioma (Protocol BT-11). Journal of Cancer Therapy, 6, 334-344. http://dx.doi.org/10.4236/jct.2015.64036 
in the patient's body. Surgical intervention is difficult and diffuse intrinsic pontine glioma (DIPG) is considered first with poor prognosis in brain tumors. Prior statistics provided various incidences of brainstem glioma (BSG). The most recent Central Brain Tumor Registry of the United States (CBTRUS) reports only 3.6\% distribution among malignant primary brain and central nervous system (CNS) tumors by site $(\mathrm{N}=112,458)$ [1]. There is increased incidence of these tumors in childhood (ages 0 - 19) with $10.4 \%$ among 21,512 patients [1]. BSG becomes rare again in young adults with incidence of $2.6 \%(\mathrm{~N}=27,899)$ [1]. These tumors are typically diagnosed by magnetic resonance imaging (MRI) [2]-[4]. Tissue diagnosis was seldom obtained due to technical difficulties, but now is more common. Approximately $80 \%$ are DIPG, which carry the worst prognosis with less than $7 \%$ of patients surviving beyond 2 years [4]. The other types include focal, exophytic, cervicomedullary and midbrain tumors. Except for DIPG, the other subcategories of pediatric BSG, as well as BSG in adults, have better prognoses, and reach the overall survival rate at 5 years over 45\% [1] [4]-[6]. Based on the most recent studies, pediatric DIPG forms a distinct group that is characterized by mutations in the histone H3.3 (H3F3A gene) [7]. Antineoplastons are peptides and amino acid derivatives that inhibit the growth of neoplastic cells without growth inhibition of normal cells [8]. Antineoplaston (ANP) A10 injection is a 4:1 mixture of phenylacetylglutaminate (PG) and phenylacetylisoglutaminate (isoPG) sodium, and ANP AS2-1 injection is a 4:1 mixture of phenylacetate sodium (PN) and PG [8]. The study of the affect of PG and PN on human U87 glioblastoma (GBM) cells indicated that PG and PN interrupt signal transduction in RAS/MAPK/ERK and PI3K/AKT/PTEN pathways, interfere with cell cycle, decrease metabolism and promote apoptosis in GBM cells. The effect on multiple cellular pathways and over 100 targets suggests that ANP is a promising candidate for clinical studies in malignant brain tumors [9].

Standard radiation therapy (RT) remains the main treatment for DIPG despite numerous clinical trials with pharmacological agents. Non-diffuse intrinsic pontine glioma (NDIPG) is more frequently biopsied and chemotherapy is based on the results of that biopsy. Initial clinical trials of ANP in 20 subjects with astrocytomas have shown complete responses (CRs) in 2 cases of DIPG in young adults [10]. They were followed by a number of successful phase II studies in children and adults [11]-[17]. In the recently published report on phase II studies in recurrent pediatric DIPG (RPDIPG), 29.5\% of patients obtained CR and PR and $17.6 \%$ had SD [13]. Serious complications in using ANP in RPDIPG included Grade 3 hypernatremia in 18\%, somnolence in $12 \%$ and hypokalemia, urinary incontinence and fatigue in 6\% [13]. The medications from the ANP group do not cause any problems of interactions with other conventional therapies [18] [19].

This study was designed to assess the efficacy and safety of ANP in patients diagnosed with BSG. Due to the large volume of data, the first part of the study describing RPDIPG has been published already [13]. This paper reports on the patients in the study with NDIPG brainstem gliomas.

\section{Patients and Methods}

\subsection{Patient Population}

As described before, recruited patients were over 3 years of age and had radiologic evidence of brainstem glioma by gadolinium-enhanced MRI performed within 14 days before initiating the study [13]. The diagnosis made by an MRI without the necessity of a biopsy is generally accepted when the following criteria for DIPG are used. Based on MRI only, DIPG can be diagnosed if the tumor has an epicenter in the pons and involves more than $50 \%$ of the pons. Patients with neurofibromatosis are not covered by this definition and were not included. The tumors involving less than $50 \%$ of the pons or exophytic infiltrating the pons were classified as DIPG if they had anaplastic or GBM histology [3] [20] [21]. The remaining types of brainstem gliomas included focal pontine, exophytic, cervicomedullary, and midbrain tumors [22] [23].

Eligibility criteria included a Karnofsky Performance Status (KPS) of 60 - 100. The details of the eligibility criteria and the removal from the study were previously published [13].

All study subjects and/or guardians read, understood, and signed written informed consent prior to enrollment. This study was conducted in accordance with the U.S. Code of Federal Regulations, Title 21, Parts 11, 50, 56, and 312; the Declaration of Helsinki (1964) including all amendments and revisions; the Good Clinical Practices: Consolidated Guideline (E6); International Conference on Harmonization; and the Food and Drug Administration (FDA) Guidance for Industry. The study was sponsored by the Burzynski Research Institute, Inc. (BRI) and conducted by the Burzynski Clinic (BC) in Houston, Texas. The patients did not pay for the investigational agents. 


\subsection{Study Design}

The study was designed as a single-arm, two-stage, interventional Phase II trial of ANP as monotherapy in a high-risk, poor-prognosis study population. The study was listed by the National Cancer Institute (NCT000034 59). It was supervised by the independent Institutional Review Board (BRI-IRB, BC-BT-11).

The study was performed according to Protocol BT-11 which was submitted to the FDA under the IND 43,742. The study commenced on March 13, 1996, and closed to accrual on January 10, 2007. Subsequently, the protocol was amended by BRI several times; however, none of the amendments altered the aim or design of the original study objectives/outcomes. Initial protocol excluded adult patients, but based on the FDA's communication on May 15, 1996, the admission criteria were amended to also accept adults.

The study design called for initial 20 patients to be accrued followed by an additional 20 patients. A total of 40 patients were enrolled to the study, as required and statistically significant results were reported to the FDA. Subgroups RPDIPG and NDIPG were analyzed separately because these were the only homogenous groups in the entire brainstem glioma population of the study.

\subsection{Statistical Considerations}

The sample size was calculated based upon the previously used method described by Chang et al. [24]. Overall survival (OS) was measured from the first day of ANP administration until death from any cause. The distributions of survival were estimated by Kaplan-Meier analysis.

ANP A10 and AS2-1 were delivered via a dual-channel infusion pump and single-lumen subclavian catheter (Broviac or Groshong) every 4 hours. The effective dose was defined as the universal dosage which in previous studies was associated with an objective response (OR); (CR + partial response (PR)). The subject continued the daily administration of 6 doses of A10 and AS2-1 (every 4 hours via automated pump) until OR was determined. The subject was then advised to continue treatment for at least eight months after an OR was documented. ANP treatment was stopped at the patient's request or if their clinical condition worsened.

The details of the administration of ANP and additional medications, including corticosteroids, were published before [12] [13].

\subsection{Evaluation and Follow-up}

The products of the two greatest perpendicular diameters of all lesions measured on MRIs were calculated and totaled, providing a baseline evaluation for each study subject. The overall tumor size was also measured including T2 and FLAIR images [21] [25]. The evaluation criteria were described before [13].

During the study the generally accepted criteria for evaluation of responses in glioma changed toward reliance on OS rather than tumor responses. As a result, the protocol was amended to include also survival analysis.

Blood, urine, and radiological tests were conducted as described before [13]. Toxicity was evaluated in all patients enrolled (NDIPG) and graded according to the Common Terminology Criteria for Adverse Events, Version 3.0 (CTCAE v3.0).

\section{Results}

\subsection{Patient Demographics}

Subject enrollment started on March 13, 1996, and continued through January 16, 2007. The total of 40 patients was accrued in the study, but one of them did not meet eligibility criteria. This patient was initially thought to have midbrain and thalamic tumor, but was later confirmed as thalamic anaplastic astrocytoma.

The 39 BSG candidates who met eligibility criteria had a median age of 11.7 years old. The distribution between the genders was $44 \%$ female and $56 \%$ male, and the majority of subjects (84.7\%) were Caucasian.

Patient demographics did not change during the study and were comparable to the other studies conducted on brainstem glioma.

The most important patient subgroup within the safety or efficacy study involved 17 children with RPDIPG. The results of treatment of these patients were published before [13].

Among the second group of patients who were diagnosed with NDIPG, there were four cases of focal pontine and four cases of cervicomedullary tumors, two cases of midbrain and one exophytic BSG. The results of treat- 
ment of this group are described in detail in this paper.

The remaining patients were subdivided into two groups: DIPG Non-recurrent Pediatric Patients $(N=7)$ and DIPG in Adult Patients $(\mathrm{N}=4)$. These two groups were too small for statistical evaluation and were not described in this paper.

Table 1 shows characteristics of 28 patients divided into the two main patient subgroups: RPDIPG and NDIPG. Table 2 summarizes confirmation of diagnosis, recurrence and responses. The results of the treatment of the RPDIPG patients were published before, but are shown here again for the reader's convenience [13].

Table 1. Study population demographics.

\begin{tabular}{|c|c|c|}
\hline Characteristics & RPDIPG $N=17$ & NDIPG $N=11$ \\
\hline \multicolumn{3}{|l|}{ Age (years) } \\
\hline Median & 8.8 & 13.4 \\
\hline Range & $4.5-18.5$ & $3.8-40.7$ \\
\hline \multicolumn{3}{|l|}{ Gender } \\
\hline Male & 8 & 8 \\
\hline Female & 9 & 3 \\
\hline \multirow[t]{3}{*}{ Ethnicity } & C-15, O-1, H-1 & C-9, A-2 \\
\hline & Tumor Type & \\
\hline & $N$ & $N$ \\
\hline DIPG & 17 & \\
\hline Focal & & 4 \\
\hline Cervicomedullary & & 4 \\
\hline Midbrain & & 2 \\
\hline Exophytic & & 1 \\
\hline Recurrent tumors & 17 & 4 \\
\hline Progressive tumors & & 7 \\
\hline \multicolumn{3}{|c|}{ Karnofsky Performance Score } \\
\hline \multirow{3}{*}{ Median } & $\mathrm{BT} / \mathrm{AT}$ & $\mathrm{BT} / \mathrm{AT}$ \\
\hline & $70 / 80$ & $90 / 90$ \\
\hline & \multicolumn{2}{|l|}{ Prior Treatment (\%) } \\
\hline None & 0 & 64 \\
\hline SU & 6 & 9 \\
\hline RT & 29 & 9 \\
\hline $\mathrm{SU}+\mathrm{RT}$ & 0 & 9 \\
\hline $\mathrm{CH}$ & 6 & 0 \\
\hline $\mathrm{CH}+\mathrm{RT}$ & 53 & 0 \\
\hline $\mathrm{HO}+\mathrm{RT}$ & 0 & 9 \\
\hline $\mathrm{SU}+\mathrm{CH}+\mathrm{RT}$ & 6 & 0 \\
\hline
\end{tabular}

Note: This group of BSG patients includes only RPDIPG and NDIPG. A-African American; AT — at the end of treatment; BSG — brainstem glioma; BT — at treatment start; C—Caucasian; $\mathrm{CH}$-Chemotherapy; DIPG—diffuse intrinsic pontine glioma; H-Hispanic; HO-Hormonal; NDIPG—non-DIPG; O_Oriental; RPDIPG_-recurrent pediatric DIPG; RT-radiation therapy; SU-surgery. 
Table 2. Confirmation of diagnosis, treatment, recurrence and response of different types of non-diffuse intrinsic pontine gliomas.

\begin{tabular}{|c|c|c|c|c|c|c|c|c|c|c|c|}
\hline \multicolumn{5}{|c|}{ Confirmation of Diagnosis } & \multirow{3}{*}{$\begin{array}{c}\text { Prior } \\
\text { Treatment }\end{array}$} & \multirow{2}{*}{\multicolumn{2}{|c|}{$\begin{array}{l}\text { Confirmation of Recurrence } \\
\text { Before Treatment Start }\end{array}$}} & \multirow{2}{*}{\multicolumn{4}{|c|}{$\begin{array}{c}\text { Confirmation of Response to ANP } \\
\text { Tumor Measurements }\end{array}$}} \\
\hline \multicolumn{3}{|c|}{ Pathology } & \multicolumn{2}{|c|}{ Radiology } & & & & & & & \\
\hline $\begin{array}{l}\text { Patient } \\
\text { ID No. }\end{array}$ & $\begin{array}{c}\text { Place } \\
\text { and Date }\end{array}$ & Diagnosis & $\begin{array}{l}\text { Place and } \\
\text { Date }\end{array}$ & Diagnosis & & $\begin{array}{l}\text { Place and Date } \\
\text { Assessment }\end{array}$ & $\begin{array}{l}\text { Percentage } \\
\text { of Pons } \\
\text { T2 }\end{array}$ & $\begin{array}{c}\text { Place } \\
\text { and Date }\end{array}$ & $\begin{array}{c}\text { MRI } \\
\text { Assessment } \\
\text { Enhancing }\end{array}$ & $\begin{array}{l}\text { MRI Non- } \\
\text { enhancing }\end{array}$ & PET \\
\hline
\end{tabular}

\section{Focal Tumors}

\begin{tabular}{|c|c|c|c|c|c|c|c|c|c|c|c|}
\hline 18 & $\begin{array}{c}\text { Not } \\
\text { Performed }\end{array}$ & $\begin{array}{c}\text { Regional } \\
\text { Medical } \\
\text { Center } \\
\text { March 27, } \\
1996 \\
\text { Research } \\
\text { Institute } \\
\text { April } 1996\end{array}$ & $\begin{array}{c}\text { Glioma, } \\
\text { Pontine } \\
\text { Glioma, } \\
\text { Focal }\end{array}$ & None & NA & 16 & $\begin{array}{c}\text { CRR } \\
\text { June 20, } \\
1997\end{array}$ & CR & Negative & Negative & \\
\hline 19 & $\begin{array}{c}\text { Not } \\
\text { Performed }\end{array}$ & $\begin{array}{c}\text { University } \\
\text { December } \\
\text { 30, } 1998\end{array}$ & $\begin{array}{c}\text { Pontine } \\
\text { Glioma, } \\
\text { Focal }\end{array}$ & RT & $\begin{array}{c}\text { Regional } \\
\text { radiology } \\
\text { May 18, } 1999 \\
\text { Recurrence }\end{array}$ & 32 & $\begin{array}{c}\text { Regional } \\
\text { Radiology } \\
\text { June 23, } \\
1999\end{array}$ & PD & Increased & Increased & \\
\hline 20 & $\begin{array}{c}\text { Not } \\
\text { Performed }\end{array}$ & $\begin{array}{c}\text { Regional } \\
\text { Radiology } \\
\text { May 16, } \\
2003\end{array}$ & $\begin{array}{l}\text { Pontine } \\
\text { Glioma, } \\
\text { Multifocal }\end{array}$ & None & NA & 16 & $\begin{array}{l}\text { Regional } \\
\text { Radiology } \\
\text { July 2, } \\
2004\end{array}$ & CR & Resolved & Reduced & Negative \\
\hline 21 & $\begin{array}{c}\text { Not } \\
\text { Performed }\end{array}$ & $\begin{array}{c}\text { Research } \\
\text { Institute } \\
\text { May 24, } \\
2006\end{array}$ & $\begin{array}{c}\text { Pontine } \\
\text { Glioma, } \\
\text { Focal }\end{array}$ & None & NA & 39 & $\begin{array}{c}\text { CRR } \\
\text { October } \\
23,2006\end{array}$ & SD & Stable & Stable & \\
\hline
\end{tabular}

\section{Cervicomedullary Tumors}

$22 \quad$ Not

Regional

Radiology

June 12, Glioma,

1996 Cervicomedullary

None

NA

NA Not

Performed

NE

University

University

23 November

18, 1991

September

1991

Brainstem

Glioma,

S University

ST July 3, 1996

Recurrence

NA $\quad \begin{gathered}\text { Not } \\ \text { Performed }\end{gathered}$

NE

1996

Regional

Medical

Brainstem

$\begin{array}{cc} & \begin{array}{c}\text { Regional } \\ \text { Medical } \\ \text { NA } \quad \text { Center }\end{array}\end{array}$

Center

July 15,
1996

Glioma,

Cervicomedullary

None

NA

January 6,

1997

$\begin{array}{cc}\text { University } & \text { Brainstem } \\ \text { August 23, } & \text { Glioma, } \\ 1996 & \text { Cervicomedullary }\end{array}$

$\begin{array}{lc} & \text { Regional } \\ \text { RT } & \text { radiology } \\ \text { HO } & \text { May 2,1997 } \\ & \text { Recurrence }\end{array}$

Regional
Radiology

September

4, 1997

$$
\text { SD }
$$

Stable Stable

\section{Midbrain Tumors}

Regional

Radiology 1

December 2, Brainstem

Not

26 Performed

$\begin{array}{cc}1996 & \text { Glioma-Midbrai } \\ \text { Regional } & \text { Brainstem }\end{array}$

Radiology 2 Glioma-Midbrain

March 11,

1997

NA

NA

CRR

November CR Negative Negative 18, 1997

CRR

NA

NA 


\section{Continued}

\begin{tabular}{|c|c|c|c|c|c|c|c|c|c|}
\hline \multicolumn{10}{|c|}{ Exophytic Tumors } \\
\hline 28 & $\begin{array}{c}\text { University } \\
\text { August 8, } \\
1996\end{array}$ & PA & $\begin{array}{c}\text { University } \\
\text { August 8, } \\
1996\end{array}$ & $\begin{array}{l}\text { Brainstem } \\
\text { Glioma, } \\
\text { Exophytic }\end{array}$ & $\mathrm{S}$ & $\begin{array}{c}\text { Regional } \\
\text { radiology } \\
\text { December 5, } \\
1996 \\
\text { Recurrence }\end{array}$ & NA & $\begin{array}{c}\text { Not } \\
\text { Performed }\end{array}$ & $\mathrm{NE}$ \\
\hline
\end{tabular}

Note: Pediatric recurrent DIPG patients 1 - 17 were previously reported in the article entitled "The response and survival of children with recurrent diffuse intrinsic pontine glioma based on phase II study of antineoplastons A10 and AS2-1 in patients with brainstem glioma” in Child’s Nervous System 2014; DOI 10.1007-S00381-014-2401-Z.

Note: AA—anaplastic astrocytoma; A2—astrocytoma Grade 2; ANP—antineoplastons; C—chemotherapy,; CR—complete response; CRR—central radiology review; DIPG—diffuse intrinsic pontine glioma; HO—hormonal; MRI—-magnetic resonance imaging; NA—not applicable; NE—not evaluable; PA—pilocytic astrocytoma; PD—progressive disease; PET—-positron emission tomography; RT—radiation therapy; S—surgery; SD—stable disease.

\subsection{Treatment Plan}

The median daily dose of ANP A10 for NDIPG (11 patients) ranged from 2.79 to $13.23 \mathrm{~g} / \mathrm{kg} / \mathrm{d}$ with a median of $8.58 \mathrm{~g} / \mathrm{kg} / \mathrm{d}$. For AS2-1, the median daily dose was $0.30 \mathrm{~g} / \mathrm{kg} / \mathrm{d}$, with a range of 0.23 to $0.49 \mathrm{~g} / \mathrm{kg} / \mathrm{d}$.

The median daily dose of A10 in subjects until OR was observed was $9.23 \mathrm{~g} / \mathrm{kg} / \mathrm{d}$; (range 7.18 to $10.72 \mathrm{~g} / \mathrm{kg} / \mathrm{d}$ ) and the median daily dose of AS2-1 was $0.30 \mathrm{~g} / \mathrm{kg} / \mathrm{d}$; (range 0.23 to $0.34 \mathrm{~g} / \mathrm{kg} / \mathrm{d}$ ). The median time to first OR was 20.14 weeks (range 15 to 36 weeks).

In the group of subjects with a SD response, the median daily dose of A10 was $14.31 \mathrm{~g} / \mathrm{kg} / \mathrm{d}$ (range 4.50 to $21.01 \mathrm{~g} / \mathrm{kg} / \mathrm{d}$ ) and the median daily dose of AS2-1 was $0.39 \mathrm{~g} / \mathrm{kg} / \mathrm{d}$ (range 0.30 to $0.50 \mathrm{~g} / \mathrm{kg} / \mathrm{d}$ ). The duration of IV ANP therapy ranged from 19 to 102 weeks with a median of 44 weeks.

All CR patients from the NDIPG group were eligible for a maintenance oral treatment of A10 and AS2-1 capsules following the ANP intravenous (IV) therapy.

\subsection{Efficacy}

Responses to treatment are summarized in Table 3. The table shows the data for all eligible RPDIPG and NDIPG populations.

In the RPDIPG group $(\mathrm{N}=17)$ there were five cases of OR $(29.5 \%)$; one CR (6\%) and four PR (23.5\%), three patients (17.5\%) had stable disease (SD), seven patients (41\%) developed PD and two cases (12\%) were non-evaluable (NE) (no follow-up MRI).

In the NDIPG group $(\mathrm{N}=11)$, there were four cases of CR $(36 \%)$, three cases of SD (27.5\%), one case of PD (9\%) and three NE cases (27.5\%) (Figure 1).

\subsection{Survival Data}

The Kaplan-Meier overall survival curve for the NDIPG group is shown in Figure 2.

Estimated overall survival for the NDIPG group at 1, 5, 10 and 15 years is $82 \%, 73 \%, 62 \%$ and $50 \%$ correspondingly to March 3, 2015. The data on 6 patients who survived from over 8 to 18 years are shown in Table 4 . One of these patients died, but there were 6 patients currently surviving in very good condition from the commencement of treatment from 8 to over 18 years.

Three patients diagnosed with focal pontine and midbrain tumors are surviving tumor-free and in excellent condition from over 14 to 18 years from the treatment start. One of these patients delivered two healthy children. An additional patient diagnosed with a cervicomedullary tumor underwent tumor resection in 2000 and lives a normal tumor-free life at present. Another patient with focal pontine glioma, whose response was classified as SD, still has the tumor, but is asymptomatic and surviving in excellent condition. Patient ID 20 was initially diagnosed with von Hippel-Lindau (VHL) disease and multifocal pontine glioma. Molecular genetic studies (MGS) revealed the complete deletion of one allele of the VHL gene. He obtained OR after five months of ANP treatment. A repeat MGS, after three months of treatment, did not show a detectable lesion or point mutation in the VHL gene. Five years later, his local oncologist was of the opinion that the patient developed central nervous system (CNS) lymphoma, for which there was no pathology confirmation. Subsequently, he was treated with chemotherapy and passed away 10 years after the treatment start with ANP. 
Table 3. Response rates.

\begin{tabular}{ccccccc}
\hline \multirow{2}{*}{ Diagnosis } & \multirow{2}{*}{$N$} & \multicolumn{5}{c}{ Response $N(\%)$} \\
\cline { 3 - 7 } & & CR & PR & SD & PD & NE \\
\hline RPDIPG & 17 & $1(6)$ & $4(23.5)$ & $3(17.5)$ & $7(41)$ & $2(12)$ \\
NDIPG & 11 & $4(36)$ & & $3(27.5)$ & $1(9)$ & $3(27.5)$ \\
\hline
\end{tabular}

Note: CR—complete response; N—number; NDIPG—non-DIPG; NE—non-evaluable; PD— progressive disease; PR-partial response; RPDIPG—recurrent pediatric DIPG; SD—stable disease.
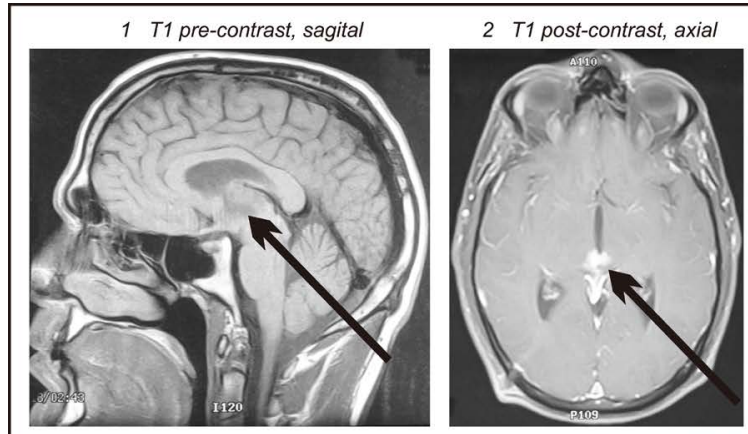

$3 \quad T 2$

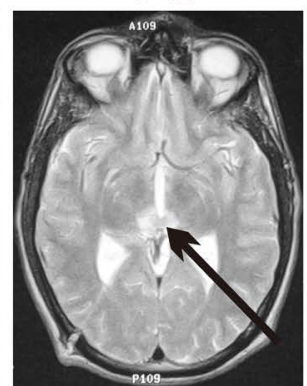

4 FLAIR
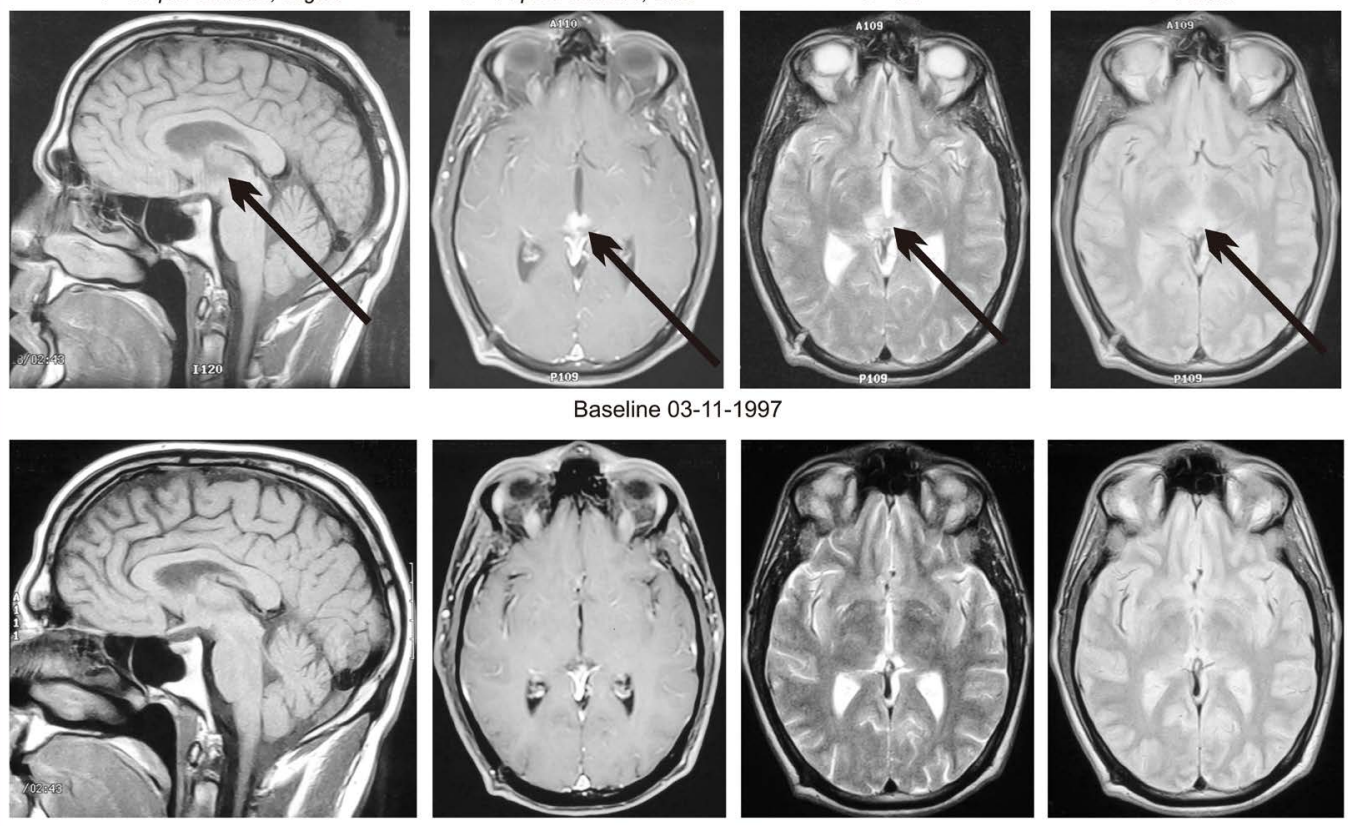

Patient 26

Figure 1. Brainstem glioma (midbrain tumor) in 29-year-old male (case 26) who did not receive prior treatment. MRI of the head 1) T1 pre-contrast; 2) T1 post-contrast; 3) T2 weighted images; and 4) FLAIR weighted images. The follow-up MRI of November 18, 1997 documents a complete response. Arrows indicate the tumors.

\subsection{Safety and Adverse Events}

Safety assessments were analyzed based upon the total number of NDIPG patients in the study $(\mathrm{N}=11)$ and are presented in Table 5 [13].

A profile of grades 3 and 4 adverse drug events (ADEs) identified and reported by the patients in this study, in comparison to the study with temozolomide, is shown in Table 6 [26]. Brain tumor patients frequently receive corticosteroids as part of their therapeutic regimen to reduce cerebral edema around tumors. The use of corticosteroids, the infusion of large volumes of sodium-containing solutions during ANP therapy, and the brain tumor itself predispose a patient to an increased incidence of serum sodium and potassium concentration abnormalities. As a result, Grade 4 hypokalemia $(2.4 \mathrm{mmol} / \mathrm{L})$ was reported in 1 patient $(9 \%)$, but there was no Grade 3 . No long-term ADEs to ANP were reported.

\section{Discussion}

The majority of patient who were enrolled in the study were diagnosed with DIPG $(\mathrm{N}=28)$. There was a homogenous group of 17 patients with RPDIPG which was described in detail before. In this group objective res- 


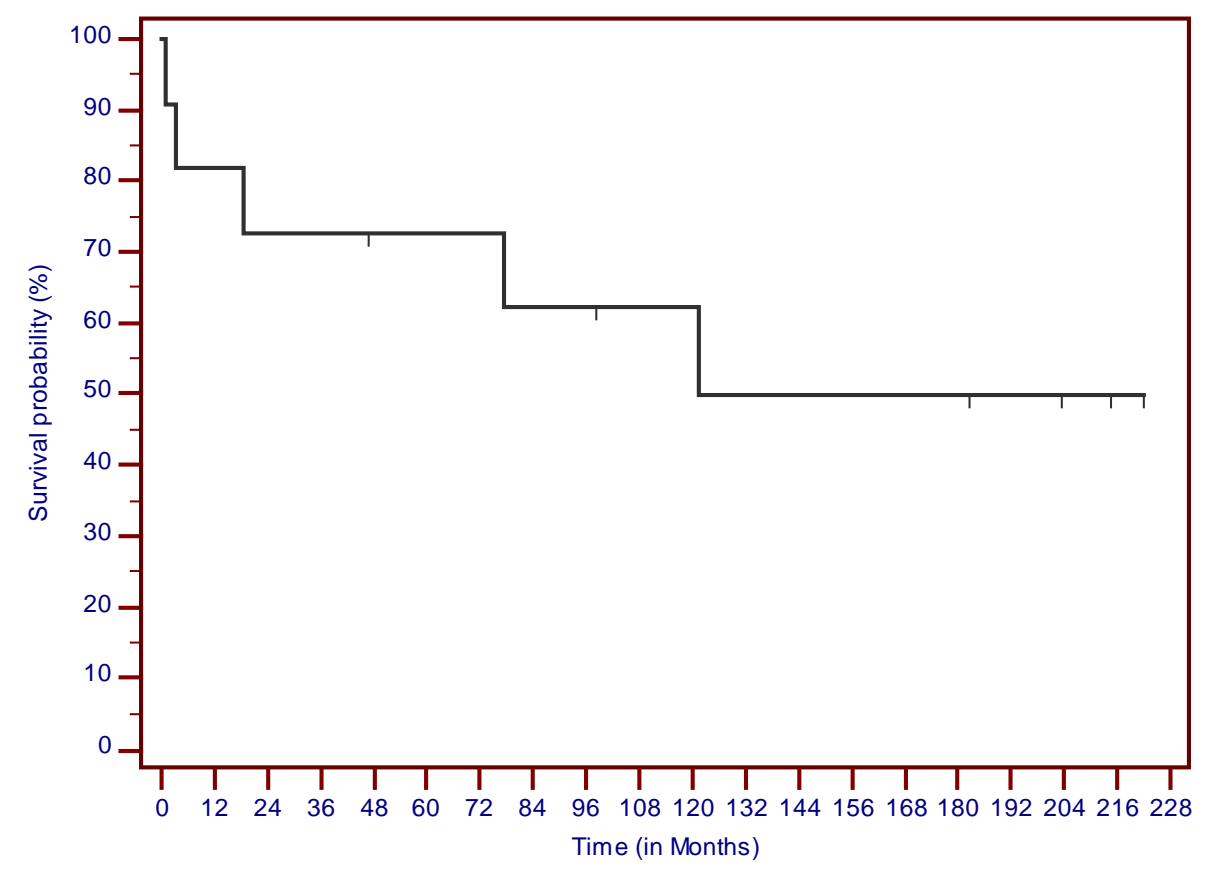

Figure 2. The Kaplan-Meier survival curve from treatment start for NDIPG.

Table 4. Long-term survival of NDIPG patients.

\begin{tabular}{|c|c|c|c|c|c|c|c|}
\hline $\begin{array}{l}\text { Patient ID } \\
\text { Number }\end{array}$ & $\begin{array}{l}\text { Diagnosis, } \\
\text { Date }\end{array}$ & $\begin{array}{c}\text { ANP } \\
\text { Start Date }\end{array}$ & $\begin{array}{c}\text { Response } \\
\text { Assessment, } \\
\text { Date }\end{array}$ & $\begin{array}{l}\text { Confirmation of } \\
\text { Survival, Date }\end{array}$ & $\begin{array}{l}\text { Overall } \\
\text { Survival } \\
\text { (Years) }\end{array}$ & $\begin{array}{l}\text { Additional } \\
\text { Treatment }\end{array}$ & $\begin{array}{c}\text { Patient's Condition } \\
\text { at Confirmation } \\
\text { of Survival }\end{array}$ \\
\hline 18 & $\begin{array}{l}\text { Pontine glioma, } \\
\text { focal March } \\
\text { 27, } 1996\end{array}$ & May 8, 1996 & $\begin{array}{c}\text { CR } \\
\text { June } 20,1997\end{array}$ & $\begin{array}{c}\text { Alive } \\
\text { November } \\
11,2014\end{array}$ & 18.51 & None & Very good \\
\hline 20 & $\begin{array}{l}\text { Pontine glioma, } \\
\text { multifocal } \\
\text { May 16, } 2003\end{array}$ & July 30, 2003 & $\begin{array}{c}\text { CR } \\
\text { July 2, } 2004\end{array}$ & $\begin{array}{c}\text { Dead } \\
\text { September } \\
10,2013\end{array}$ & 10 & $\begin{array}{l}\text { Chemotherapy for } \\
\text { CNS lymphoma, } \\
\text { no pathology } \\
\text { confirmation }\end{array}$ & N/A \\
\hline 21 & $\begin{array}{c}\text { Pontine glioma, } \\
\text { focal May 24, } 2006\end{array}$ & July 28, 2006 & $\begin{array}{c}\text { SD } \\
\text { October 23, } 2006\end{array}$ & $\begin{array}{c}\text { Alive } \\
\text { October 6, } 2014\end{array}$ & 8 & None & Very good \\
\hline 25 & $\begin{array}{l}\text { Brainstem glioma, } \\
\text { cervicomedullary } \\
\text { August 23, } 1996\end{array}$ & May 6, 1997 & $\begin{array}{c}\text { SD } \\
\text { September } \\
\text { 4, } 1997\end{array}$ & $\begin{array}{c}\text { Alive } \\
\text { April 22, } 2014\end{array}$ & 17 & $\begin{array}{c}\text { Tumor Resection, } \\
2000\end{array}$ & Very good \\
\hline 26 & $\begin{array}{l}\text { Brainstem glioma, } \\
\text { midbrain tumor } \\
\text { December 2, } 1996\end{array}$ & $\begin{array}{l}\text { March 13, } \\
1997\end{array}$ & $\begin{array}{c}\text { CR } \\
\text { November } \\
18,1997\end{array}$ & $\begin{array}{c}\text { Alive } \\
\text { January 26, } 2015\end{array}$ & 18 & None & Very good \\
\hline 27 & $\begin{array}{l}\text { Brainstem glioma, } \\
\text { astrocytoma, Grade } 2 \\
\text { of midbrain, thalamus } \\
\text { and hypothalamus } \\
\text { June } 17,1999\end{array}$ & July 23, 1999 & $\begin{array}{c}\text { CR } \\
\text { November } \\
\text { 8, } 1999\end{array}$ & $\begin{array}{c}\text { Alive } \\
\text { October 7, } 2014\end{array}$ & 15 & None & Very good \\
\hline
\end{tabular}

Note: ANP—antineoplastons; CNS—central nervous system; CR—complete response; N/A— not applicable; NDIPG-non-diffuse intrinsic pontine glioma; SD—stable disease.

ponses were determined in $29.5 \%$ of patients, 1 year overall survival was $29.4 \%$ and 2 years survival was $11.8 \%$. There was an additional group of six children with newly diagnosed and one previously treated child with non-recurrent DIPG. There are no ORs identified in this group, and these populations were too small for statistical analysis. Likewise, there were no ORs in four adults with recurrent DIPG. 
Table 5. Toxicity for NDIPG patients according to CTCAE v3.0.

\begin{tabular}{ccccc}
\hline Adverse Drug Event & G1 (\%) & G2 (\%) & G3 (\%) & G4 (\%) \\
\hline Dehydration & - & 9.1 & - & - \\
Dry mouth/salivary gland (xerostomia) & 9.1 & 9.1 & - & - \\
Fatigue (asthenia, lethargy, malaise) & 18.2 & 18.2 & - & - \\
Hypokalemia & - & - & - & - \\
Nausea & 9.1 & 9.1 & - & - \\
Taste alteration (dysgeusia) & 9.1 & 9.1 & - & - \\
Urinary frequency/urgency & 27.3 & 9.1 & - & - \\
\hline
\end{tabular}

Note: CTCAE v3.0—common terminology criteria for adverse events version 3.0; G—Grade; NDIPG—non-diffuse intrinsic pontine glioma.

Table 6. Incidence (\%) of adverse drug events, Grades 3 and higher, reported in antineoplaston treatment of NDIPG compared to the studies of chemotherapy for pediatric brain tumors.

\begin{tabular}{ccc}
\hline Adverse Drug Event Incidence & Burzynski et al., Antineoplastons (\%) & Lashford et al., 2002 [26] Temozolomide (\%) \\
\hline Hypokalemia & 9 & 1 \\
Fatigue & & 7 \\
Thrombocytopenia & 5 \\
Leukopenia & 2 \\
Vomiting & $<1$ \\
Anorexia & 2 \\
Sepsis & 2 \\
Pneumonia & $<1$ \\
Neuropathy & $<1$ \\
Seizures & $<1$ \\
Pain & $<$ \\
\hline
\end{tabular}

Note. NDIPG—non-diffuse intrinsic pontine glioma.

In the second largest group of 11 patients diagnosed with NDIPG, there was 36\% CR and $27.5 \% \mathrm{SD}$. The NDIPG cases were inoperable and included four focal pontine, four cervicomedullary, two midbrain tumors, and a single exophytic tumor.

The group of 6 NDIPG patients survived in excess of 8 to 18 years.

The results in the RPDIPG group were previously compared with the results of all recent clinical trials in RPDIPG and revealed a significantly higher OR and OS. Separate clinical trials were not conducted on NDIPG and for this reason an accurate comparison is not possible. The number of patients enrolled with RPDIPG and NDIPG is small (17 and 11), but in the range of other studies. A recently published phase II study of sorafenib in low-grade astrocytoma enrolled only 11 patients [27].

It is known that the survival of NDIPG patients is much better than in the DIPG group and the main treatment modality is surgery [4] [28]-[30]. Unfortunately for non-resectable cases, the remaining options are radiation therapy and chemotherapy. CRs in the NDIPG group and very long OS with an excellent quality of life compares favorably to the results of standard treatment. Such cases are incurable and they die, despite the standard treatment, after suffering with a crippling disease. Excellent recovery, normal quality of tumor-free life, and a very long survival of a number of cases gives hope that in some patients, these tumors can be eradicated. Future genomic studies may provide the rationale for response in these patients.

\section{Conclusion}

The progress in basic research on brain tumors in recent years has been remarkable, but these results have not 
yet been translated into practical application for the curative treatment of inoperable brainstem glioma. The report on the study of ANP in patients with NDIPG, according to protocol BT-11, provides encouraging CRs and PRs, especially for focal pontine and midbrain gliomas and offers encouraging long-term survival. Additional studies on genomic signature and clinical trials should provide more detailed information. The FDA has given permission for the Phase III clinical study in DIPG and it can be performed at multiple sites.

\section{Conflict of Interest}

All authors are employed by Burzynski Clinic. Dr. Stanislaw R. Burzynski and Dr. Gregory S. Burzynski are shareholders and directors, and Dr. Tomasz J. Janicki is the vice-president of Burzynski Research Institute, Inc.

\section{Acknowledgements}

The authors express their appreciation to the additional physicians involved in the care of the patients: Drs. Robert A. Weaver, Robert I. Lewy, Alejandro Marquis, Eva Kubove, Barbara Szymkowski, Sheryll Acelar, and Mohammad Khan. Preparation of the manuscript was provided by Carolyn Powers, Maria Corzo and Jennifer Pineda. Editorial assistance was provided by Malcolm Kendrick, M.D.

\section{References}

[1] Ostrom, Q.T., Gittleman, H., Liao, P., Rouse, C., Chen, Y.W., Dowling, P., et al. (2014) CBTRUS Statistical Report: Primary Brain and Central Nervous System Tumors Diagnosed in the United States in 2007-2011. Neuro-Oncology, 16, iv1-iv63. http://dx.doi.org/10.1093/neuonc/nou223

[2] Barkovich, A.J., Krischer, J., Kun, L.E., Packer, R., Zimmerman, R.A., et al. (1990) Brain Stem Gliomas: A Classification System Based on Magnetic Resonance Imaging. Pediatric Neurosurgery, 16, 73-83. http://dx.doi.org/10.1159/000120511

[3] Albright, A.L., Packer, R.J., Zimmerman, R., Rorke, L.B., Boyett, J., Freeman, C.R., et al. (2013) Magnetic Resonance Scans Should Replace Biopsies for the Diagnosis of Diffuse Brain Stem Gliomas: A Report from the Children's Cancer Group. Neuro- Oncology, 15, 1026-1030.

[4] Donaldson, S.S., Laningham, F. and Fisher, P.G. (2006) Advances toward an Understanding of Brainstem Gliomas. Journal of Clinical Oncology, 24, 1266-1272. http://dx.doi.org/10.1200/JCO.2005.04.6599

[5] Hargrave, D., Bartels, U. and Bouffet, E. (2006) Diffuse Brainstem Glioma in Children: Critical Review of Clinical Trials. Lancet, 7, 241-248. http://dx.doi.org/10.1016/S1470-2045(06)70615-5

[6] Burzynski, S.R. (2007) Recent Clinical Trials in Diffuse Intrinsic Brainstem Glioma. Cancer Therapy, 5, 379-390.

[7] Khuong-Quang, D.A., Buczkowicz, P., Rakopoulos, P., Liu, X.Y., Fontebasso, A.M., et al. (2012) K27M Mutation in Histone H3.3 Defines Clinically and Biologically Distinct Subgroups of Pediatric Diffuse Intrinsic Pontine Gliomas. Acta Neuropathologica, 124, 439-447. http://dx.doi.org/10.1007/s00401-012-0998-0

[8] Burzynski, S.R. (2004) The Present State of Antineoplaston Research (1). Integrative Cancer Therapies, 3, 47-58. http://dx.doi.org/10.1177/1534735403261964

[9] Burzynski, S.R. and Patil, S. (2014) The Effect of Antineoplastons A10 and AS2-1 and Metabolites of Sodium Phenylbutyrate on Gene Expression in Glioblastoma Multiforme. Journal of Cancer Therapy, 5, 929-945. http://dx.doi.org/10.4236/jct.2014.510099

[10] Burzynski, S.R., Kubove, E. and Burzynski, B. (1992) Phase II Clinical Trials of Antineoplastons A10 and AS2-1 Infusions in Astrocytoma. In: Adam, D. Ed., Recent Advances in Chemotherapy, Futuramed Publishers, Munich, 25062507.

[11] Burzynski, S.R. (2006) Treatments for Astrocytic Tumors in Children: Current and Emerging Strategies. Pediatric Drugs, 8, 167-168. http://dx.doi.org/10.2165/00148581-200608030-00003

[12] Burzynski, S.R., Janicki, T.J., Burzynski, G.S. and Marszalek, A. (2013) Long-Term Survival (>13 Years) in a Child with Recurrent Diffuse Pontine Gliosarcoma: A Case Report. Journal of Pediatric Hematology/Oncology, 36, e433e439. http://dx.doi.org/10.1097/MPH.0000000000000020

[13] Burzynski, S.R., Janicki, T.J., Burzynski, G.S., Marszalek, A. (2014) The Response and Survival of Children with Recurrent Diffuse Intrinsic Pontine Glioma Based on Phase II Study of Antineoplastons A10 and AS2-1 in Patients with Brainstem Glioma. Child's Nervous System, 30, 2051-2061. http://dx.doi.org/10.1007/s00381-014-2401-z

[14] Burzynski, S.R., Janicki, T.J., Burzynski, G.S. and Marszalek, A. (2014) A Phase II Study of Antineoplastons A10 and AS2-1 in Children with High-Grade Glioma. Final Report (Protocol BT-06), and Review of Recent Trials. Journal of 
Cancer Therapy, 5, 565-577. http://dx.doi.org/10.4236/jct.2014.56065

[15] Burzynski, S.R., Janicki, T.J. and Burzynski, G.S. (2014) A Phase II Study of Antineoplastons A10 and AS2-1 in Adult Patients with Recurrent Glioblastoma Multiforme: Final Report (Protocol BT-21). Journal of Cancer Therapy, 5, 946-956. http://dx.doi.org/10.4236/jct.2014.510100

[16] Burzynski, S.R., Janicki, T.J., Burzynski, G.S., Marszalek, A. and Brookman, S. (2014) A Phase II Study of Antineoplastons A10 and AS2-1 in Children with Recurrent, Refractory or Progressive Primary Brain Tumors-Final Report (Protocol BT-22). Journal of Cancer Therapy, 5, 977-988. http://dx.doi.org/10.4236/jct.2014.510102

[17] Burzynski, S.R., Burzynski, G.S. and Janicki, T.J. (2014) Recurrent Glioblastoma Multiforme-A Strategy for LongTerm Survival. Journal of Cancer Therapy, 5, 957-976. http://dx.doi.org/10.4236/jct.2014.510101

[18] Burzynski, S.R., Janicki, T.J., Burzynski, G.S. and Brookman, S. (2014) Preliminary Findings on the Use of Targeted Therapy with Pazopanib and Other Agents in Combination with Sodium Phenylbutyrate in the Treatment of Glioblastoma Multiforme. Journal of Cancer Therapy, 5, 1423-1437. http://dx.doi.org/10.4236/jct.2014.514144

[19] Burzynski, S.R., Burzynski, G.S. and Brookman, S. (2015) A Case of Sustained Objective Response of Recurrent/ Progressive Diffuse Intrinsic Pontine Glioma with Phenylbutyrate and Targeted Agents. Journal of Cancer Therapy, 6, 40-44. http://dx.doi.org/10.4236/jct.2015.61006

[20] Packer, R.J., Boyett, J.M., Zimmerman, R.A., Rorke, L.B., Kaplan, A.M. (1993) Hyperfractionated Radiation Therapy (72 Gy) for Children with Brain Stem Gliomas. A Childrens Cancer Group Phase I/II Trial. Cancer, 72, 1414-1421.

[21] Wen, P.Y., Macdonald, D.R., Reardon, D.A., Cloughesy, T.F., Sorensen, A.G., et al. (2010) Updated Response Assessment Criteria for High-Grade Gliomas: Response Assessment in Neuro-Oncology Working Group. Journal of Clinical Oncology, 28, 1963-1972. http://dx.doi.org/10.1200/JCO.2009.26.3541

[22] Choux, M., Lena, G. and Do, L. (2000) Brainstem Tumors. In: Choux, M., Di Rocco, C. and Hockley, A., Eds., Pediatric Neurosurgery, Churchill Livingstone, New York, 471-491.

[23] Leach, P.A., Estlin, E.J., Coope, D.J., Thorne, J.A. and Kamaly-Asl, I.D. (2008) Diffuse Brainstem Gliomas in Children: Should We or Shouldn't We Biopsy? British Journal of Neurosurgery, 22, 619-625. http://dx.doi.org/10.1080/02688690802366198

[24] Chang, S.M., Kuhn, J.G., Robins, H.I., Schold, S.C., Spence, A.M., et al. (1999) Phase II Study of Phenylacetate in Patients with Recurrent Malignant Glioma: A North American Brain Tumor Consortium Report. Journal of Clinical Oncology, 17, 984-990.

[25] Weller, M., Cloughesy, T., Perry, J.R. and Wick, W. (2013) Standards of Care for Treatment of Recurrent Glioblastoma-Are We There Yet? Neuro-Oncology, 15, 4-27. http://dx.doi.org/10.1093/neuonc/nos273

[26] Lashford, L.S., Thiesse, P., Jouvet, A., Jaspan, T., Couanet, D., et al. (2002) Temozolomide in Malignant Gliomas of Childhood: A United Kingdom Children's Cancer Study Group and French Society for Pediatric Oncology Intergroup Study. Journal of Clinical Oncology, 20, 4684-4691.

[27] Karajannis, M.A., Legault, G., Fisher, M.J., Milla, S.S., Cohen, K.J., et al. (2014) Phase II Study of Sorafenib in Children with Recurrent or Progressive Low-Grade Astrocytomas. Neuro-Oncology, 16, 1408-1416. http://dx.doi.org/10.1093/neuonc/nou059

[28] Mauffrey, C. (2006) Paediatric Brainstem Gliomas: Prognostic Factors and Management. Journal of Clinical Neuroscience, 13, 431-437.

[29] Guillamo, J.S., Monjour, A., Taillandier, L., Devaux, B., Varlet, P., Haie-Meder, C., et al. (2001) Brainstem Gliomas in Adults: Prognostic Factors and Classification. Brain, 124, 2528-2539. http://dx.doi.org/10.1093/brain/124.12.2528

[30] Kesari, S., Kim, R.S., Markos, V., Drappatz, J., Wen, P.Y. and Pruitt, A.A. (2008) Prognostic Factors in Adult Brainstem Gliomas: A Multicenter, Retrospective Analysis of 101 Cases. Journal of Neuro-Oncology, 88, 175-183. http://dx.doi.org/10.1007/s11060-008-9545-1 